\title{
Chapter 3 \\ Effects of Climate Change \\ on the Hydrological Cycle \\ in Central and Eastern Europe
}

\author{
Judith Stagl, Elisabeth Mayr, Hagen Koch, Fred F. Hattermann, \\ and Shaochun Huang
}

\subsection{Introduction}

Water is involved in all components of the climate system: the atmosphere, hydrosphere, cryosphere, land surface and biosphere. The dynamics of the water cycle are one of the key variables that determine the distribution and productivity of ecosystems. Changes in hydrology influence plant and animal species in various ways. Almost all land-dependent life, habitats and ecosystems depend of freshwater. Similarly, water plays a key role in the climatic system. The water cycle is a key process upon which other cycles of the climate system operate. It acts as an energy transfer and storage medium through the hydrological cycle. Globally, changes in water vapour content of the atmosphere, cloud cover and ice influence the radiation balance of the earth and thus play an important role in determining the climate response to increasing greenhouse gas emissions (Bates et al. 2008). Hence, changes in climate are intricately interlinked with changes to the hydrological cycle - the most important feedback cycle in the climate system.

For the management of protected areas knowledge about the water regime plays a very important role, in particular in areas with wetlands, marches or floodplains as well as lakes. The local hydrological conditions depend widely on temporal and spatial variations of the main components of the hydrologic cycle and the physiographic conditions on site. In many protected areas, especially those with existing

J. Stagl $(\bowtie) \bullet$ H. Koch $・$ F.F. Hattermann $・$ S. Huang

Potsdam Institute for Climate Impact Research,

P.O. Box 601203, 14412 Telegrafenberg, Potsdam, Germany

e-mail: judith.stagl@pik-potsdam.de; hagen.koch@pik-potsdam.de;

hattermann@pik-potsdam.de; huang@pik-potsdam.de

E. Mayr

Department of Geography, Faculty of Geosciences, Ludwig-Maximilians-Universität

München, Luisenstrasse 37, 80333, Munich, Germany

e-mail: e.mayr@geographie.uni-muenchen.de 
conflicts of interests (e.g. agriculture) between stakeholders, water management measures are implemented since many years. Such measures mainly focus on the regulation of water levels in lakes, rivers and groundwater through the construction of slices, locks, drainage channels or artificial reservoirs, with high impacts to the local biodiversity. To preserve a favourable conservation status under changing climatic conditions park managers require information about potential impacts of climate change in their area. Climate change projections from regional climate models can provide such information, even though with a low spatial resolution (several $\mathrm{km}^{2}$ ) concerning biodiversity. Hydrological models can downscale these information and investigate potential impacts of climate change or management measures to the local water regime like river runoff, lake levels or water availability in an area. The projected changes due to climate change vary significantly across Central and Eastern Europe. Hence, the following chapter provides an overview of how climate change affects the hydrological regimes in Central and Eastern Europe. It focuses on the underlying processes and which general hydrological impacts can be expected in the light of climate change. First of all, major processes of the water cycle on river catchment scale are explained. Furthermore, changes of the most important water cycle processes due to climate change, precipitation and evapotranspiration, as well as climatically indicator for the potential water availability the climatic water balance are summarised. This leads to the impacts on river flow regimes and changes the inter- and intra-annual variability, which are described in the following sub-section. The subsequent chapter shows the role of water resources management on stream flow and its availability to counterbalance effects of climate change. Finally, climate change impacts on the glaciers in the European Alps as important storage component are illustrated.

\subsection{Overview About the Hydrological Cycle}

The hydrological cycle describes the continuous circulation of water between ocean, atmosphere and land. Water is transferred through physical processes like evapotranspiration, precipitation, infiltration and river runoff. This circle from one reservoir to another involves energy exchange in terms of heat transfer, solar radiation and gravitational potential energy. During these processes water can change its aggregation state (liquid, vapour, or ice) various times. Hydrological processes encompass a variety of spatial and temporal scales. At the river catchment scale, the hydrological cycle comprises precipitation as major input, various transfer processes, different storages and outputs. They are referred to by hydrologists as components of the water balance.

Precipitation is condensed water vapour and mostly occurs as rain, but also includes snow, hail, drizzle, sleet and fog drip. Snow can accumulate and eventually 


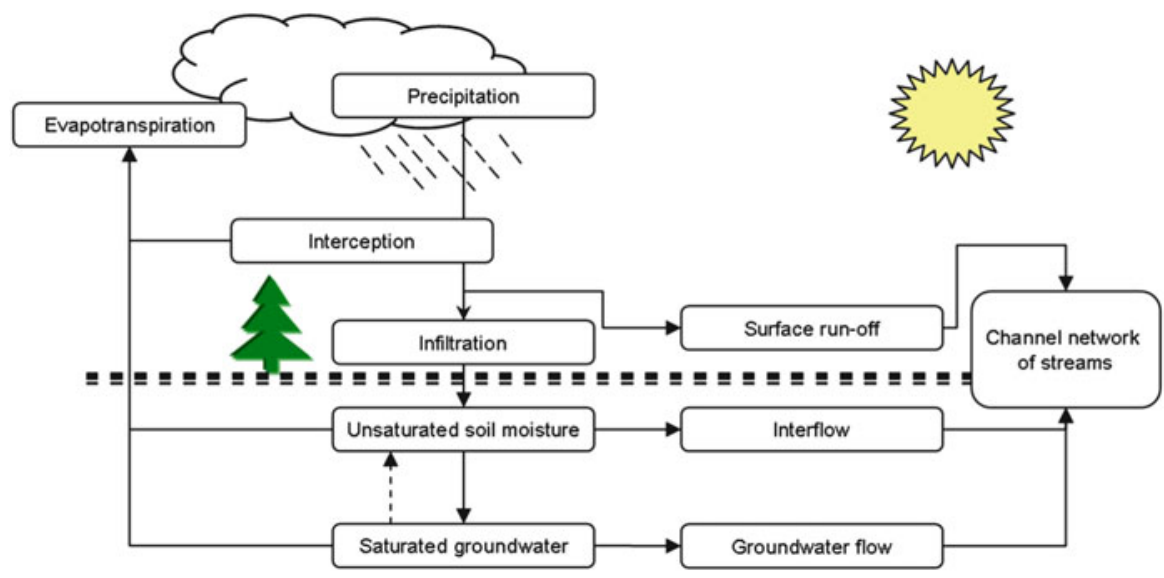

Fig. 3.1 Hydrological components on catchment scale

compact to form glaciers and ice caps. In case of ice and snow, the water stored is released to the cycle with delay as a function of temperature. Rainfall type, volume and intensity are a decisive factor for further processes in the catchment. Factors controlling evaporation are the amount of incident solar radiation, the vapour pressure of the air relative to saturation, air temperature, wind circulation and atmospheric pressure. About 600 calories of energy per gram of water is exchanged during the change from a liquid to a gaseous state. Transpiration accounts for loss of water vapour through plant stomata. Besides in snow and ice covers, water can be held on the canopy surface, which includes plant foliage, branches and stems. From this so called interception store, it eventually evaporates to the atmosphere without reaching the soil surface. If rainfall intensity exceeds the soil's infiltration capacity, surface runoff occurs. The respective infiltration rate depends mainly on the texture and structure as well as the initial moisture content of the soil. Water infiltrated can be held in the unsaturated soil dependent on the amount lost by plant uptake, evaporation, groundwater recharge, or interflow (see Fig. 3.1).

Interflow characterises the downslope transfer of water through the soil towards river channels. The groundwater storage is replenished slowly by deep percolation and can be a long-term reservoir of the water cycle (with residence time from days to millennia). Groundwater flow is the slow movement of water within the saturated zone of an aquifer under the influence of gravity or hydrostatic pressure. River runoff in streams is composed of surface runoff, interflow, groundwater flow and direct precipitation. The flow process that dominates on a slope are a function of several variables, including climate, vegetation, rainfall characteristics, soil thickness, slope morphology, and human interferences. The velocity of runoff in (river) stream channels is controlled by the gradient and shape of the channel, and its roughness caused by the presence of bed load, i.e. stones, and vegetation. 


\subsection{Climate Change Impacts on the Water Regime for Central Europe}

\subsubsection{Precipitation, Evaporation and Climatic Water Balance}

In Central and Eastern Europe the mean temperature is projected to increase between 1 and $3{ }^{\circ} \mathrm{C}$ in the next decades and up to $5{ }^{\circ} \mathrm{C}$ until the end of the century (see Chap. 2). A general pattern is that the higher temperatures lead to an intensification of the water cycle (EEA 2008). Based on the Clausius-Clapeyron expression for saturation vapour pressure, the moisture holding capacity of air increases by about $7 \%$ per $1-^{\circ} \mathrm{C}$ increase in air temperature (Baumgartner and Liebscher 1990). As a result, climate warming will lead to an increase of the evaporative demand in the air, or "potential evaporation". Generally a higher moisture potential in the atmosphere ultimately leads amongst others to changes in rainfall patterns.

Key changes to the hydrological cycle in Central Europe associated with an increased concentration of greenhouse gases in the atmosphere include (Goudie 2006):

Changes in the seasonal distribution and amount of precipitation. Generally, for all scenarios, the projected annual mean precipitation increases in northern Europe and decreases in the south of Europe. In doing so, the changes in precipitation patterns vary from season to season and across regions in response to changes in large-scale circulation and water vapour loading (Bates et al. 2008). A substantial decrease is projected in summer precipitation for most parts of Central Europe. Because precipitation comes primarily from moisture convergence, an increase in the atmospheric water holding capacity increases the potential for intense precipitation (Trenberth et al. 2003). At the same time this leads to a decrease in the frequency and duration of precipitation events, making way for longer dry periods between precipitation events (IPCC 2007).

Increased evapotranspiration and a reduction in soil moisture. As a result of higher temperature the water vapour deficit in the atmosphere increases. In areas with sufficient (surface) water availability this leads to an increase in actual evapotranspiration. With scarce precipitation, this enlarges the risk of drought as surface drying and hence, a reduction on soil moisture is forced up (Bates et al. 2008). Additionally, an increased atmospheric $\mathrm{CO}_{2}$-concentration directly alters plant physiology and thus transpiration rates (especially C3 plants).

Changes in the balance between snow and rain. As temperature rises, the likelihood of precipitation falling as rain rather than snow increases, especially in areas where temperatures are near freezing point, and at the beginning and end of the snow season. Yet a warmer climate leads to a shorter snow season with more rains but reduced snow packs, earlier snowmelt and greater ablation. Such changes are already observed in many places, especially over land in high latitudes of the Northern Hemisphere (Bates et al. 2008). As for some areas in Central and Eastern Europe a general increase in winter precipitation is projected, this effect could partly compensate a reduction of the total amount of snow, even if the percentage of precipitation falling as snow is decreasing. 


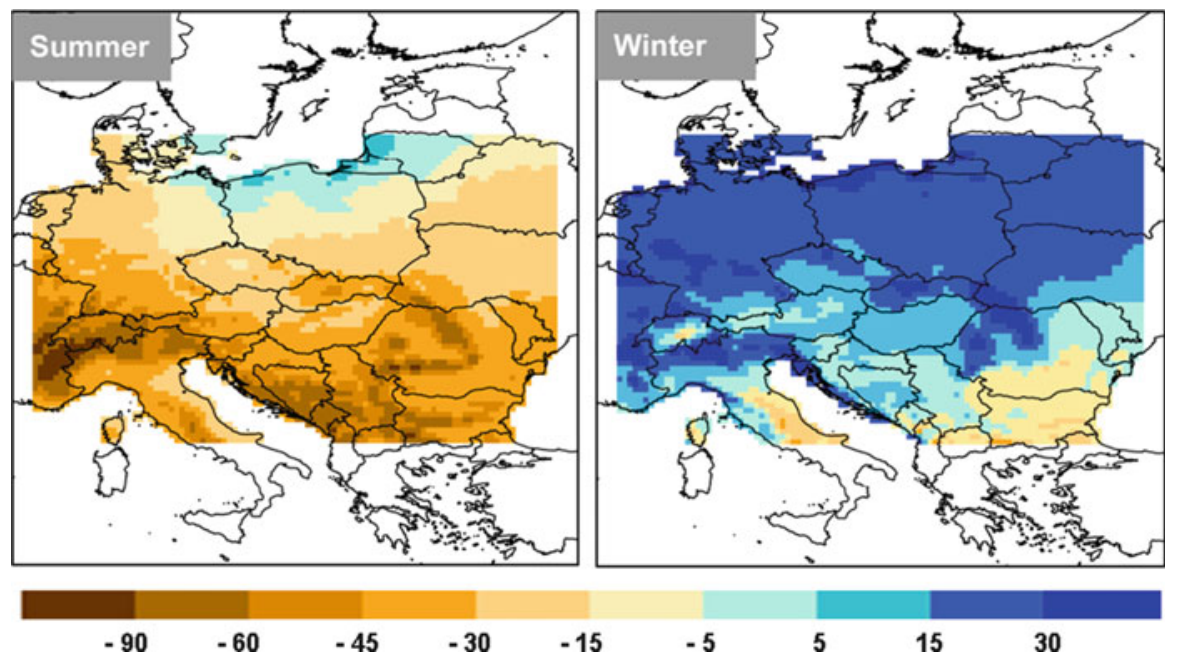

Fig. 3.2 Change of Climatic Water Balance in Central and Eastern Europe for winter (December-February) and summer (June-August) as the multi-model mean 2036-2065 relative to 1971-2000 [absolute differences in $\mathrm{mm} / 3$ months], for the A1B greenhouse gas emission scenario with 14 different GCM-RCM-combinations from the ENSEMBLES project (van der Linden and Mitchell 2009)

By the use of the Climatic Water Balance (CWB) expected changes on the potential water availability due to climate change can be illustrated. The CWB is defined as the amount of precipitation minus the potential evapotranspiration. It indicates the extent of the water yield in an area and provides an indication for the vegetation on-site.

If the potential evapotranspiration is higher than the amount of precipitation the CWB turns out to be negative and there is a climatic water deficit. A positive water balance indicates a climatic water surplus for the area. For the results shown in Fig. 3.2 the potential evapotranspiration is calculated with the TURC-IVANOVmethod by DVWK (1996) and the monthly coefficients by Glugla and König (1989). For Central Europe an increase of the Climatic Water Balance is projected for the winter months with exception of the southern parts. In summer (June to August) the potential water availability tends to decrease in whole Central Europe (see Fig. 3.2).

\subsubsection{Climate Change Impacts on River Runoff}

River runoff consists of a portion of precipitation that is not evaporated, transpired or stored, e.g. by soils. Variations on river runoff are determined by climatic conditions like precipitation and temperature as well as catchment characteristics and watershed management practices. In numerous studies (e.g. Huang et al. 2012; 
Hattermann et al. 2012) published in scientific journals potential effects of climate change in river flow regime have been examined. Most studies apply a hydrological catchment model which is driven by scenario climate data from regional climate models (dynamical or statistical) and adjusted for the investigation area (Bates et al. 2008). In the framework of the HABIT-CHANGE project the eco-hydrological watershed model SWIM (Soil and Water Integrated Model) (Krysanova et al. 1998) has been chosen to evaluate the impacts of climate change on eco-hydrological processes and water resources at a regional level provided by the Potsdam Institute for Climate Impact Research. SWIM is a continuous-time, semi-distributed watershed model, which combines hydrological processes, vegetation, erosion and nutrient dynamics at the meso- to macro-scale. After validation for the target areas, the model is used to transform changes in climate and land use into spatially distributed changes in hydrology and water resources under scenario conditions. Depending on the physiogeographical and hydrogeological characteristics, different river basins respond in different ways to the same change in climatic conditions. Uncertainties in projected changes in the hydrological system arise from internal variability of the climate system, uncertainties in future greenhouse gas and aerosol emissions, the translation of these emissions into climate change impacts by global climate models, regionalisation by regional climate models, hydrological model uncertainty and uncertainties in model input data (e.g. runoff, soil and land use data). Specific challenges in hydrological modelling are the scale difference between the climate and hydrological systems, data limitations and the effect of human interventions such as reservoir impoundment. However, modelling results can help to locate and assess possible future changes taking into account the range of uncertainty (different scenarios and models).

Changes in annual river runoff are projected to vary significantly across Europe, related to regional environmental settings and local changes in precipitation and temperature. Furthermore, changes in seasonal runoff regime and interannual runoff variability due to climate change depend primarily on changes in the amount and timing of precipitation, the evaporative demand and whether precipitation falls as snow or rain. Generally, annual river flows have been observed to slightly increase in the north and north-eastern part of Europe and to decrease in the south and south-eastern parts. Additionally, climate change leads to changes in the seasonality of river flows, particularly with a trend to lower flows in summer and higher flows in the winter months (EEA 2008, 2009).

A very robust finding of hydrological impact studies is that in snow-dominated watersheds warming would lead to changes in seasonality of river flows (Bates et al. 2008). Hence, spring flow tends to decrease in some areas as a result of reduced and earlier snowmelt and, in addition, winter flow increases by less winter precipitation falling as snow which can be stored. In some areas this effect could be diminished by a general increase in winter precipitation, even if the ratio of snow related to the total amount decreases. Summer flow in river basins with considerable groundwater contribution will change in accordance with changes in precipitation during the groundwater recharge period in winter. In regions with little or no 

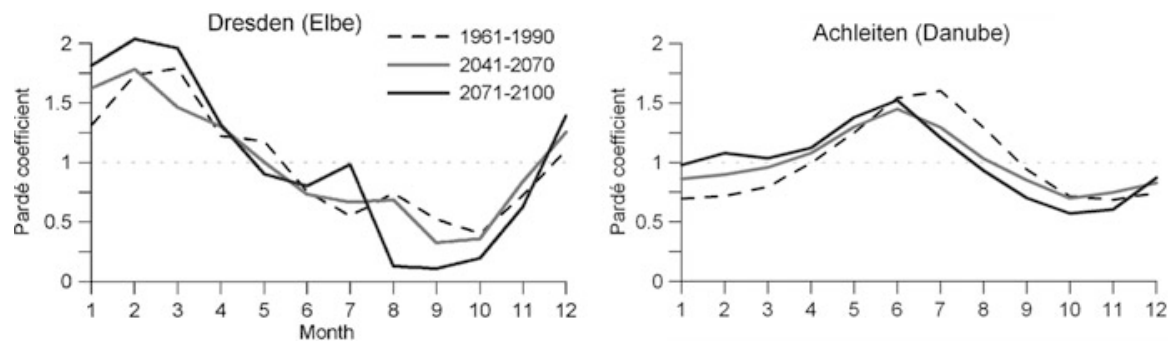

Fig. 3.3 Monthly Pardé-coefficients $(\mathrm{PC}=\mathrm{Q}$ mean monthly/Q mean annual) simulated by the eco-hydrological model SWIM (Krysanova et al. 2000) driven by regional climate simulation from REMO for the A1B greenhouse gas emission scenario for gauge Achleiten at Danube river and gauge Dresden at Elbe river for three different time slices (long-term annual mean values for 1961-1990, 2041-2070 and 2071-2100)

snow fall, changes in river flow are much more dependent on changes in rainfall than on changes in temperature (Bates et al. 2008). Due to the non-linearity of response, the changes in river flow will always be considerably higher in percentage than the changes in the precipitation amount. Many studies in such regions project an increase in flow seasonality, often with higher flows in the peak flow season and lower flows during the low-flow season. Though, in most cases the timing of peak and low flows remains virtually unchanged (IPCC 2007).

River flow regimes can be described as the average seasonal behaviour of flow. Differences in the regularity of the seasonal patterns reflect different dimensionalities of the flow regimes, which can change due to changes in climate conditions. For Fig. 3.3 the non-dimensional monthly Pardé-coefficients are used to describe the annual distribution of discharge at two characteristic river gauges. The gauge Achleiten in the upper Danube catchment represents a mainly snow driven regime (nivo-pluvial), while the gauge Dresden in the upper Elbe catchment can be described as pluvial regime (rain-dominated). Figure 3.3 illustrates the expected shifts in the seasonality of river flows described above.

Future climate scenarios indicate a likelihood to more frequent floods in the next decades for many European regions, particularly in winter and spring (EEA 2008). Flood magnitudes are expected to increase where floods result from increasingly heavy rainfall events. Furthermore flood magnitudes are projected to decrease in regions where floods are generated by snowmelt (Kundzewicz et al. 2012). Despite the considerable rise in the number of reported major flood events over recent decades in Europe, no conclusively climate-related trend in extreme high river flows could be detected in observations up to now (EEA 2010; Pińskwar et al. 2012; Kundzewicz et al. 2012). River engineering and water management practices alter the river conveyance system over time which complicates the detection of climate change signals in observed river discharge data. Concurrently, the observed upward trend in flood damages can mostly be attributed to socio-economic factors and land use changes (Kundzewicz et al. 2012). 


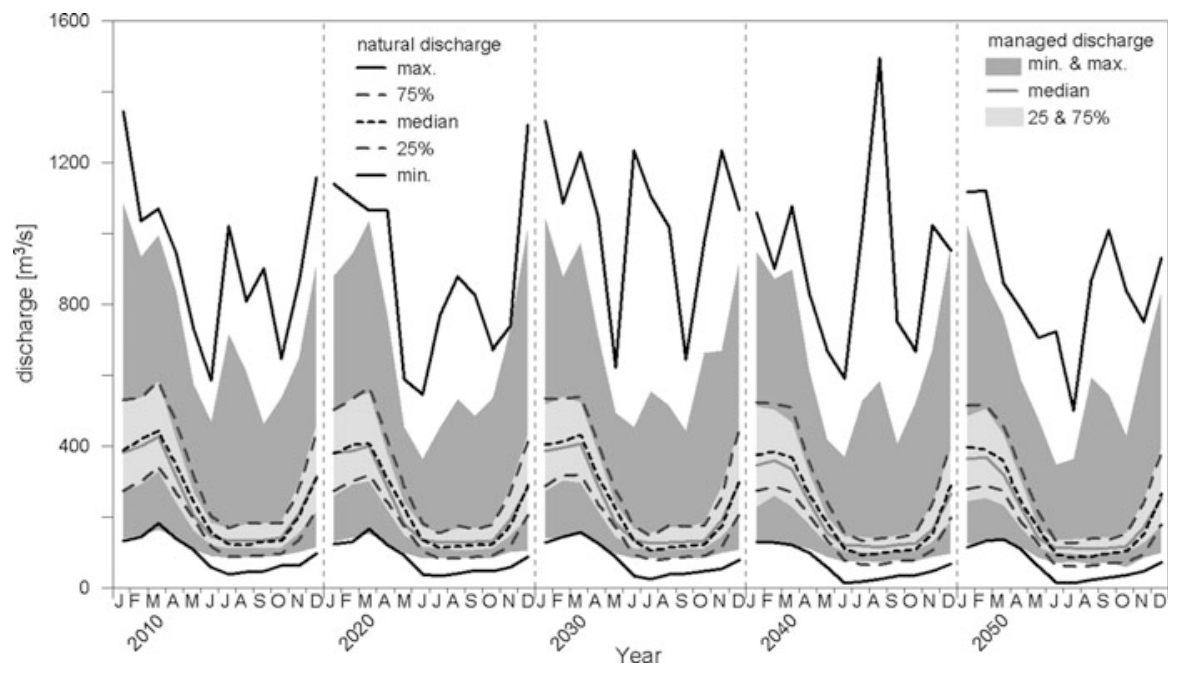

Fig. 3.4 Natural discharge (model SWIM) and managed streamflow (model WBalMo) at gauge Hrensko/Labe (Czech Republic) for the years 2010-2050 displayed as a 5-year average (e.g. "2010" stands for multi-year average of 2008-2012)

\subsubsection{Water Resources Management Impacts on Streamflow}

Besides climate change and land use change direct human interventions can affect natural runoff processes. When analysing the effects of such changes a clear differentiation between the natural discharge affected by climate change and land use change, and managed streamflow should be made. Therefore particularly in regions with large anthropogenic water use or water management effects, e.g. reservoir management or water transfers, natural runoff processes and the resulting natural discharge should be distinguished from measured (and managed) streamflow. In the project GLOWA-Elbe (Wechsung et al. 2011) an eco-hydrological model for the river Elbe basin was developed to simulate the effects of climate change and land use change on natural runoff. A water resources management model was used to simulate the effects of water management on streamflow and water availability. In the example presented in Fig. 3.4 climate change and land use change are considered in the simulation of the (unmanaged) natural runoff using the eco-hydrological model SWIM. From 100 realisations of future climate data, all assuming a temperature increase of approximately $1.8{ }^{\circ} \mathrm{C}$ by 2055 , a corresponding number of realisations of natural discharge are generated (Conradt et al. 2012). This natural discharge is an important input for the water resources management model. Simulated in the water resources management model (WBalMo ${ }^{\circledR}{ }^{1}$ Elbe) are all relevant water users with their water demand and return flows, and the management of the water infrastructure, i.e. reservoirs and water transfers.

\footnotetext{
${ }^{1}$ WBalMo is a registered trademark of DHI-WASY Ltd.
} 
The river Elbe basin with a catchment area of approximately $150,000 \mathrm{~km}^{2}$ is located in Central Europe (Czech Republic, Germany, Austria and Poland). Especially in the mountainous upper parts of the Czech Republic a number of large reservoirs are concentrated. These reservoirs are used to regulate the streamflow in the rivers Vltava/Moldau and Labe/Elbe, and to promote navigation and other water uses. As an example for the different quantities simulated by SWIM (natural discharge) and successive by WBalMo Elbe (managed streamflow) the flow at gauge Hrensko is displayed in the Fig. 3.4. The results are presented for the years 2010-2050, where 2010 stands for the time period 2008-2012 and so on. Since 100 realisations are used, 500 values ( 5 years * 100 realisations) are available for the statistical analysis for each time step of the respective time period.

Especially for dry periods in summer a decline of the natural low flows is simulated, e.g. "min" of natural discharges. The minimum managed streamflow in summer months is higher compared to the natural discharge, due to low flow augmentation by reservoirs and discharges from wastewater treatment plants etc. However, for mean conditions the differences between natural discharge and managed streamflow are rather small. During periods of high flows the managed streamflow is lower compared to the natural discharge, because water is used to refill the reservoirs. Overall the extremes caused by natural conditions are buffered by water resources management.

From Fig. 3.4 also the potential of water resources management to counterbalance effects of climate change and land use change on streamflow and water availability can be estimated. Not considered here are possibilities of adapting water management to changing conditions.

\subsubsection{Climate Change Impacts on Glaciers}

Glaciers are considered as key indicators for the early detection of global greenhouse gas related warming trends (IPCC 2007). Moreover, glaciers itself have considerable impact on the runoff regimes of rivers with glaciated areas within their catchments. Basic requirement for the formation and persistence of glaciers is the accumulation of snow which is not entirely melted in the following summer and remains as firn till the next winter. The firn of several years compacts to ice and finally starts to flow following gravity. In Central Europe, glaciers are located in the Alps as well the Caucasus with a total ice covered area of $3,778 \mathrm{~km}^{2}$ (Zemp et al. 2008; WGMS and NSIDC 1989, updated 2012). Since their last maximum during the little ice age in the middle of the nineteenth century, most glaciers in these areas are shrinking.

In the twentieth century, annual temperature increased by $1.3^{\circ} \mathrm{C}$ for the alpine region (Auer et al. 2007). Additionally, winters in the alpine areas became drier in the last 25 years and therefore reduced the amount of snow accumulation (Zemp et al. 2008). Both processes have negative effect on the existing glaciers. 


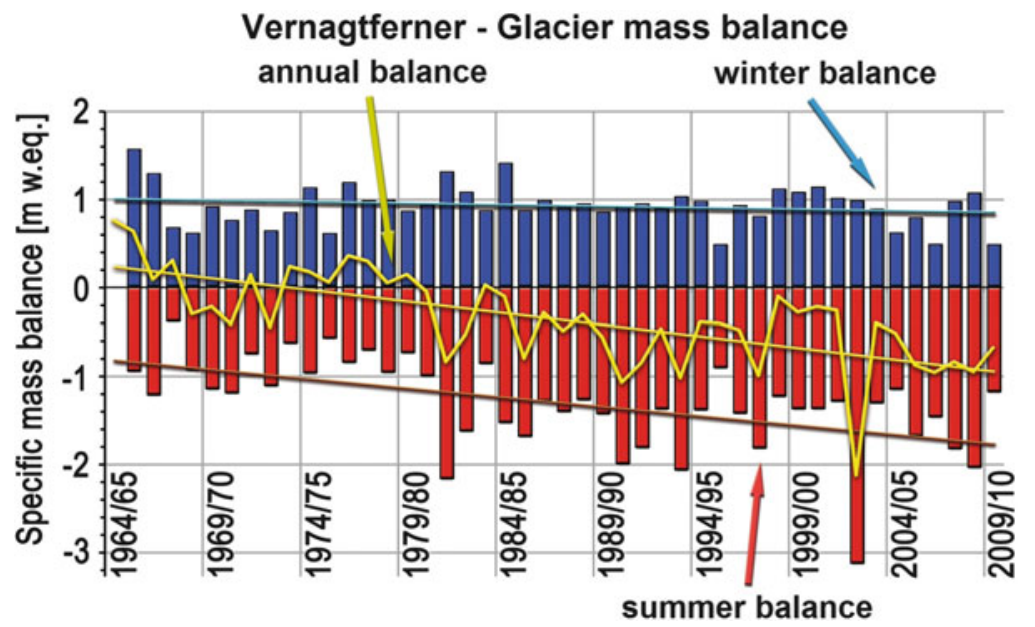

Fig. 3.5 Winter, summer and annual mass balance of the Vernagtferner in Austria for the period $1964 / 65$ to $2009 / 10$

In the Alps, glacier cover was shrinking by $35 \%$ from 1850 to the 1970 s and another $22 \%$ by 2000 (Paul et al. 2004) and also in the Caucasus a severe mass loss is evident since the little ice age (Zemp et al. 2008). In Central Europe, front variations of glaciers are observed at 764 glaciers with an average time length of 65 years. But to determine the direct reaction of a glacier to climate change, ice volume changes - the so called glacier mass balance - have to be observed. In the mid latitudes, the mass balance of a glacier is mainly dependent on winter precipitation (accumulation) and summer temperature (ablation) which are measured separately in spring and autumn. In Central Europe, these measurements are available for 43 glaciers with an average number of observations of 20 years (Zemp et al. 2008). One of the longest time series of mass balance is measured at the Vernagtferner $\left(46^{\circ} 52^{\prime} \mathrm{N} / 10^{\circ} 49^{\prime} \mathrm{E}\right)$ in Tyrol, Austria (Fig. 3.5).

Direct measurements of both, winter and summer mass balance were initiated in 1964 (Reinwarth and Escher-Vetter 1999). Winter, summer and annual mass balance since then are presented Fig. 3.5. The annual mass balance trend is negative with some positive years in the 1980s and beginning 1990s and a prominent negative peak in 2003 where a heat wave in Europe heavily accelerated the icemelt. While the winter mass balance shows just a slight decreasing over the full period, ice losses in summer are increasing considerably in the same time.

The trend of negative mass balances is therefore mainly caused by enhanced melt in summer while changes in winter accumulation have only small influence. The time series of area changes at Vernagtferner is even longer and documents a glacier shrinking from $11.6 \mathrm{~km}^{2}$ in 1889 to $7.9 \mathrm{~km}^{2}$ in 2010 . 
The influence of glaciers on runoff and the effect of changing glaciation due to climate change are of high importance for the water availability in many regions.

A glacier in equilibrium state with stable ice volumes results in a glacial runoff regime with runoff maximums during the ablation period in summer. A shrinking glacier causes increased melt water supply and enforces the glacial regime (Lambrecht and Mayer 2009). Gradually shrinking glacier areas finally lead to decreasing amounts of ice melt and therefore finally to a shift from glacial to nival runoff regime with runoff maxima shifting from July and August to May and June (Huss et al. 2008). How big these impacts are for the river runoff and the water availability is highly dependent on the climate conditions. Melt water is most important in climates which are both warm and dry and gets even more important if the river flows into an arid area. In the mid latitudes of Central Europe, the share of glacier melt to total runoff is only moderate because of the high additional precipitation input (Kaser et al. 2010).

\subsection{Conclusion}

There is convincing evidence that increasing concentrations of greenhouse gases in the atmosphere are causing a substantial rise in global temperature (IPCC 2007). As integral component of the climate system, water is the primary medium through which climate change exhibits its impacts on earth's ecosystem. Increases in temperature enhance the moisture holding capacity of the atmosphere and thus, lead to an intensification of the hydrological cycle. The hydrological impacts of climate change to the individual protected areas are area-specific and vary from region to region. Generally, key changes in the hydrological system for Central Europe include alterations in the seasonal distribution, magnitude and duration of precipitation, an increase in evapotranspiration in areas where water is available and a reduction of the snow season. This leads to variations in water storage and water fluxes at the land surface as well as in soil moisture and seasonal snow packs. Observations of central European glaciers, which are considered as key indicator for the early detection of climate change, show a severe mass loss in the last decades. Other indirect impacts of climate change include modifications in the intra- and interannual variability of river flows and an increase in the risk of flood and droughts. Through, water resources management can help to counterbalance effects of climate change on stream flow and water availability until a certain level. In general, climate-induced changes are projected to aggravate the impact of other stresses like land-use and socio-economic changes on water availability (EEA 2008).

Open Access This chapter is distributed under the terms of the Creative Commons Attribution Noncommercial License, which permits any noncommercial use, distribution, and reproduction in any medium, provided the original author(s) and source are credited. 


\section{References}

Auer, I., Bohm, R., Jurkovic, A., Lipa, W., Orlik, A., Potzmann, R., Schoner, W., Ungersbock, M., Matulla, C., Briffa, K., Jones, P., Efthymiadis, D., Brunetti, M., Nanni, T., Maugeri, M., Mercalli, L., Mestre, O., Moisselin, J. M., Begert, M., Muller-Westermeier, G., Kveton, V., Bochnicek, O., Stastny, P., Lapin, M., Szalai, S., Szentimrey, T., Cegnar, T., Dolinar, M., Gajic-Capka, M., Zaninovic, K., Majstorovic, Z., \& Nieplova, E. (2007). HISTALP - Historical instrumental climatological surface time series of the Greater Alpine Region. International Journal of Climatology, 27, 17-46.

Bates, B. C., Kundzewicz, Z. W., Wu, S., \& Palutikof, J. P. (2008). Climate change and water. Technical paper of the Intergovernmental Panel on Climate Change. Geneva: IPCC Secretariat.

Baumgartner, A., \& Liebscher, H.-J. (1990). Lehrbuch der Hydrologie I/Allgemeine Hydrologie Quantitative Hydrologie. Berlin/Stuttgart: Gebrüder Borntraeger.

Conradt, T., Koch, H., Hattermann, F. F., \& Wechsung, F. (2012). Spatially differentiated management-revised discharge scenarios for an integrated analysis of multi-realisation climate and land use scenarios for the Elbe River basin. Regional Environmental Change, 12(3), 633-648. doi:10.1007/s10113-012-0279-4.

DVWK. (Eds.). (1996). Ermittlung der Verdunstung von Land- und Wasserflächen. DVWK Merkblätter zur Wasserwirtschaft. 238. Bonn: Wirtschafts- und Verl.-Ges. Gas und Wasser.

EEA. (Eds.). (2008). Water quantity, river floods and droughts in impacts of Europe's changing climate - 2008 indicator-based assessment (Joint EEA-JRC-WHO report, EEA Report No 4/2008, European Environmental Agency). Copenhagen: European Communities.

EEA. (Eds.). (2009). Water resources across Europe - Confronting water scarcity and drought (EEA Report No 2/2009). Copenhagen: European Communities.

EEA. (Eds.). (2010). The European environment state and outlook 2010, Water resources: quantity and flows. European Environmental Agency. Copenhagen: European Communities.

Glugla, G., \& König, B. (1989). VERMO-Ein Modell für die Berechnung des Jahresganges der Evaporation, Versickerung und Grundwasserneubildung. Tag.-Bericht. Berlin: Akad. Landwirtsch.Wiss. DDR, 85-91.

Goudie, A. (2006). Global warming and fluvial geomorphology. Geomorphology, 79(3-4), 384-394.

Hattermann, F. F., Kundzewicz, Z. W., Huang, S., Vetter, T., Kron, W., Burghoff, O., Merz, B., Bronstert, A., Krysanova, V., Gerstengarbe, F.-W., Werner, P., \& Hauf, Y. (2012). Flood risk from a holistic perspective - Observed changes in Germany. In Z. W. Kundzewicz (Ed.), Changes in flood risk in Europe (pp. 212-237). Oxfordshire: IAHS Press.

Huang, S., Krysanova, V., \& Hattermann, F. F. (2012). Projection of low flow conditions in Germany under climate change by combining three REMs and a regional hydrological model. Acta Geophysica. doi:10.2478/s11600-012-0065-1.

Huss, M., Farinotti, D., Bauder, A., \& Funk, M. (2008). Modelling runoff from highly glacierized alpine drainage basins in a changing climate. Hydrological Processes, 22, 3888-3902.

IPCC. (2007). Climate change 2007. The physical science basis. Contribution of Working Group I to the fourth assessment report of the Intergovernmental Panel on Climate Change (S. Solomon, D. Qin, M. Manning, Z. Chen, M. Marquis, K. B. Averyt, M. Tignor, \& H. L. Miller, Eds.). Cambridge/New York: Cambridge University Press.

Kaser, G., Grosshauser, M., \& Marzeion, B. (2010). Contribution potential of glaciers to water availability in different climate regimes. Proceedings of the National Academy of Sciences of the United States of America, 107, 20223-20227.

Krysanova, V., Müller-Wohlfeil, D.-I., \& Becker, A. (1998). Development and test of a spatially distributed hydrological/water quality model for mesoscale watersheds. Ecological Modelling, 106(2-3), 261-289. 
Krysanova, V., Wechsung, F., Arnold, J., Srinivasan, R., \& Williams, J. (2000). SWIM (Soil and Water Integrated Model), user manual (PIK Report No. 69). Potsdam: Potsdam Institute of Climate Impact Research.

Kundzewicz, Z. W., Plate, E. J., Rodda, H. J. E., Rodda, J. C., Schellnhuber, H. J., \& Strupczewski, W. G. (2012). Changes on flood risk - Setting the stage. In Z. W. Kundzewicz (Ed.), Changes in flood risk in Europe (pp. 11-54). Oxfordshire: IAHS Press.

Lambrecht, A., \& Mayer, C. (2009). Temporal variability of the non-steady contribution from glaciers to water discharge in western Austria. Journal of Hydrology, 376, 353-361.

Paul, F., Kaab, A., Maisch, M., Kellenberger, T., \& Haeberli, W. (2004). Rapid disintegration of Alpine glaciers observed with satellite data. Geophysical Research Letters, 31, L21402.

Pińskwar, I., Kundzewicz, Z. W., Peduzzi, P., Brakenridge, G. R., Stahl, K., \& Hannaford, J. (2012). Changing flood in Europe. In Z. W. Kundzewicz (Ed.), Changes in flood risk in Europe (pp. 83-96). Oxfordshire: IAHS Press.

Reinwarth, O., \& Escher-Vetter, H. (1999). Mass balance of Vernagtferner, Austria, from 1964/65 to 1996/97: Results for three sections and the entire glacier. Geografiska Annaler Series a-Physical Geography, 81A, 743-751.

Trenberth, K. E., Dai, A., Rasmussen, R. M., \& Parsons, D. B. (2003). The changing character of precipitation. Bulletin of the American Meteorological Society, 84, 1205-1217.

van der Linden, P., \& Mitchell, J. F. B. (Eds.). (2009). ENSEMBLES: Climate change and its impacts: Summary of research and results from the ENSEMBLES project. Exeter: Met Office Hadley Centre.

Wechsung, F., Koch, H., \& Gräfe, P. (Eds.). (2011). Elbe-Atlas des globalen Wandels. Berlin: Weißensee Verlag.

WGMS \& NSIDC. (1989, updated 2012). World glacier inventory. Compiled and made available by the World Glacier Monitoring Service, Zurich, Switzerland, and the National Snow and Ice Data Center, Boulder CO, U.S.A. doi:10.7265/N5/NSIDC-WGI-2012-02.

Zemp, M., Roer, I., Kääb, A., Hoelzle, M., Paul, F., \& Haeberli, W. (2008). Global glacier changes: Facts and figures. Zürich: World Glacier Monitoring Service. 